\title{
POETIC DISCOURSE AS AN ACT OF COMMUNICATIVE INTERACTIONS BETWEEN ADDRESSER AND ADDRESSEE
}

\author{
Tetyana Yeshchenko \\ Ph.D., Associate Professor, Head of the Department of Ukrainian Studies, \\ Danylo Halytsky Lviv National Medical University, Ukraine \\ e-mail: teua.1viv@gmail.com, orcid.org/0000-0002-3624-5072
}

\section{Summary}

The author substantiates the idea of the anthropocentric nature of the poetic text, in which the addresser and the addressee form an interactive communicative chain, and artistic-poetic communication in the aspect of discursive approach is considered as a process in which the subject of verbal interaction between its participants is encoded in poetic form. Poetic verbal goals act as the source for this research, from which a selection of units that manifest the text category «anthropocentrism» is done in a way of accurate and complete inventory. The research method is descriptive. The author considers the poetic text as an intermediate link in the paradigm, which presupposes certain communicative roles of the addresser (author) and the addressee (reader). This triadic structure of speech interaction is caused by the tactical and strategic repertoire of the speaker, their intention, functional parameters of the text and pragmatic effect. The prospect of the research is the description of the text category «anthropocentrism» and its components (addresser / addressee) in semantic, pragmatic, communicative aspects.

Keywords: text, text category «anthropocentrism», addresser, addressee.

DOI https://doi.org/10.23856/4319

\section{Introduction}

Problem statement. The study of the communicative position of the speaker was mainly carried out from the perspective of the analysis of the image of the author in the literary text (V. Vovk, V. Drozdovsky, V. Vinogradov). However, the development of linguistics in the XXI century has made possible linguistic research in terms of communicative and pragmatic study of literary text and discourse, because poetic discourse is a kind of communicative event, the distinguishing features of which are the representation of information that has no pragmatic embodiment. This feature is embodied in the fact that all names in a fiction text do not have real denotations, and the context and extralinguistic conditions of existence of objects in the discourse are created by the author-addresser themselves, and its purpose is to emotionally affect the reader.

The aim of the article is to describe poetic discourse as an act of communicative interaction between the addresser and the addressee.

Sources and methods. Poetic verbal goals act as the source for this research, from which a selection of units that manifest the text category "anthropocentrism» is done in a way of accurate and complete inventory. The research method is descriptive.

\section{Main statements presentation}

The addresser and the addressee are individuals who, on the one hand, have generalized typed features of the native speaker, national culture, and on the other hand - excellent 
epistemological experience (knowledge, preferences, judgments and attitudes to the environment). Both participants of communicative interaction are characterized by a dynamic position, but it is the addresser who has a significant role in stimulating figurative and poetic communication, encouraging the addressee to creative reading and interpretation of the text, interpretation of subtexts and occasional meanings of artistic figures. Since in a poetical work, the factor of the addresser unfolds and is represented first of all through artistic figures(images). The use of tactical repertoire (tactics of presentation, reaction, etc.) is currently aimed at implementing the communication strategy chosen by the poet-speaker and ensuring the harmonious flow of artistic and figurative communication. The anthropocentric orientation of modern linguistics is precisely that the starting position in it is occupied by the addresser.

We consider addresser as one of the main components of the communicative act and as a key text-forming category.

The effect of creating a verbal whole resides in such features of metaphorical information as versatility of reflections of reality, panoramic and stereoscopic occasional-artistic image, subconscious motives in the structure of the text, where the poet-addresser combines in themselves all text categories; appears as the organizing force of the arrangement of its components into a single whole, fills it with a single worldview, determines the compositional and structural form. Precisely in the text category «addresser» artistic and figurative areas acquire their completeness - in worlds, emotions, thoughts, associations, existential meanings. We agree with the views of Tetyana Radzievska, a specialist in the theory of language communication, who states: «Text creation, which is a kind of language activity, is characterized by a high degree of complexity and can be considered as a functional system.

We agree with the views of Tetyana Radzievska, a specialist in the theory of language communication, who states: «Text creation, which is a kind of language activity, is characterized by a high degree of complexity and can be considered as a functional system which consists of some sub-systems, created by elements of communicative-pragmatic situation of text creation. These include the subject, object, addressee, purpose (intention) of communication, as well as some other components, the essence of which depends on the type of text») (Radziievska, 2010 : 244). The creation of communicative-pragmatic situations (say, poetic discourse) is determined by the human factor. On the one hand - by the addresser, who realizes the intentions and uses the right to choose associative connections in contexts, encoding the relevant information in this way, on the other hand - by the addressee, who, guided by his life and language experience, must decode it. «Modern linguistics has a solid pragmatic orientation. In this regard, the concepts of «linguistic personality», «linguistic community», «linguistic ability», «linguistic consciousness», «linguistic and communicative competences», «emotional and culturological competence», «linguo-creative activity» have become especially relevant, which is not a novelty in science, but requires fresh understanding, projections on specific objects. This applies to the representation of both a separate language community and individual language features which are prominent representatives of this linguistic and cultural community» (Kosmeda, 2012: 17). The individual and social essence of the addresser's linguistic personality is most fully manifested in textual and communicative activity. Each time the author expresses his position differently: explicitly, through words, or implicitly (hidden), through conceptual-semantic or subtextual information, figuratively-metaphorically, compare: «Коли душа ридає і розривається / На шматочки болю, / Смійся йому в душу, / Смійся йому прямісінько в його / життя» (Kruk, 1995: 51). At present, poetic texts should be considered as a verbal realization of fragments poets worldview, linguistic and literary generations, which reflects individual and social (collective, ethnospecific) worldview in their inseparable unity, 
such an realization that allows interpreting not only explicit but also verbal the personality of the addresser and their world view. The concept of «addresser» in poetic communication correlates with related concepts such as: «author» (we do not mean the image of the author, but the author himself as a person in the aggregate of his views on certain situations, aspirations, life positions, tastes, personal qualities etc.), «subject of speech», «communicator», «linguistic personality», «author's personality», «speaker». When creating a poetic text, the addresser primarily considers the effectiveness of the poetic message. Artistic figure (image) is the realization of the communicative behavior of writers, representatives of certain literary groups (associations, groups), lexical and semantic expression of the factor of the addressor. After all, lexical content, grammatical and syntactic structures are chosen by the poets and writers depending on the purpose and objectives of poetic communication. The addresser in artistic discourse is an active subject of creating a functionally oriented linguistic phenomenon as a certain type of artistic semantic subtextual message, a kind of executor of a certain informative program through the reflection of correlations in defining the components of poetic and figurative picture of the world and their embodiment in verbal and artistic figures. We can for sure say that «addressability is represented by the transformation in the text of worldviews, values, emotions of the real author in the form of author-function, which is interpreted by the real reader as a figure of the addresser» (Selivanova, 2006: 511). The addresser of the poetic discourse verbally creates a special kind of reality - poetic and metaphorical, becoming both the author of the verbal whole and the subject of artistic speech, an active participant in the communicative act. They produce artistic speech, fill it with figurative meaning, set the intensity of communicative correlation. The dominance of the addresser factor is traced in poetry, where the writer determines the form of presentation of artistic and figurative information and its content, and as we know, the creation of communicative and pragmatic situations in poetic and metaphorical discourse is determined by human factors. On the one hand, by a poet who realizes intentions and chooses associative connections in contexts, a way of coding relevant information, on the other hand, by reader who, based on his life and linguistic and cultural experience, must know it (information). The addresser of the text stimulates the addressee-reader (listener) to mental-intellectual operations, creates a basis for a reference act, establishes correspondence with extralinguistic reality. And it is the addresser-reader who is entrusted with the difficult role of recognizing the metaphorical idea of the author, giving semantic formations new meanings, and assessing the individual-creative competence of the poet-addresser. Currently, social and linguistic experience helps the recipient to recognize the referent and make sense of what is presented in the text. Thus, poetic communication is addresser- targeted, and scientific comprehension of the author's intention is impossible without taking into account the conditions of communication. Thus, poetic communication is addresser-targeted, and scientific comprehension of the author's intention is impossible without taking into account the conditions of communication. At the same time, it is extremely important to take into account both the cultural context and the set of personal, historical, and national circumstances of the formation of poetic discourse. Currently, the text is an active continuum of the formation of mental objects with the help of artistic images. The author, as a mandatory participant in the communicative-cognitive process, is the initiator, creator and sender of important, in his opinion, information. In the text, it is represented by a system of various means, each of which takes an active part in creating a network of diverse relations between the participants. What is the uniqueness of the communicative interaction between the addressee and the addressee in poetic discourse? First of all, the addressee seeks to find such communicative parameters that would allow not only to exchange information, but also to influence the feelings of the addressee, to evoke appropriate emotions, 
to form aesthetic ideals and so on. Since the creator of his own poetic world (with its lyrical heroes, poetic laws, artistic and figurative situations) in the poetic text is the addressee, he represents thoughts and emotions through the text, mentally runs ahead to determine the impact of what is written on the addressee-reader. The form of communication now comes to the fore, and its substantive part - in the background. The author-addressee of poetic-metaphorical discourse in his desire to know and explain the surrounding world absorbs it through the prism of his own feeling, integrates the verbal whole, functions in semantic innovations, in authorial artistic images, in superficial and deep text structures. Communicative and pragmatic situations represent speech priorities in the choice of certain figurative and artistic means, individual-creative ability of the speaker at the level of the text through individual-author metaphors. These are the creative beginnings of «language in action». The artistic text appears as an act of communicative interaction between the author-addresser and the reader-addressee. During such interaction, communicators use the whole arsenal of language and speech tools to achieve the goal, and if it is achieved, the communication process is considered successful. The effectiveness of the communicative process depends on how the cognitive style of the addresser and the addressee (recipients) coincides. In a specific pragmatic situation, the addresser-addressee vector of directing the discourse involves the manifestation of individual skills of poets in the realization of linguistic and creative potentials and influence on readers. Since when creating communicative-pragmatic situations for the realization of the author's intentions, the addressers often go beyond the already systematically fixed units and create new modifications, offering new semantic meanings. While the addressee factor encourages the author to uniquely convey the content and form of the verbal whole, so that they ensure the optimal impact of communication on speakers. Therefore, writers are faced with the task of bringing the artistic message as close as possible (both in terms of content and in terms of expression) to the level of education, training and character of their audience in general. The contexts can contain such unexcepted marginal units as dialectisms, slang expressions, everyday words; also the transformation of widely-used expressions known in mass culture can happen. E.g.: «Будда відпустив оселедия по плечі, / Читав бароккові євангельські мантри, / Водив за собою зграї малечі, / В корчмі заливаючи про власні мандри» (Zhadan, 1995: 11); "Так виникають міста $i$ дефініції / Хтось пропонував Гомера на мера / Історія фіксувала фікиії / 3 точністю провіниійного репортера (Haleta, 1999: 21). The addresser seeks to bring their speech as close as possible to the usual, ordinary language of streets, a kind of adaptation of literary language to the new conditions of his era. Associations and created linguistic units appear partly on the verge of paradoxical and extremely unexpected artistic images. Compare: «Птахами плаче небо восени / i падають на дно очей краплини» (Dnistrovyi, 30). The lexical-semantic representation of the addresser of poetic texts as a central pragmatic unit is their reflection as an anthropo-ethnocultural phenomenon, a tradition of transmitting figurative and artistic information. Identifying the intentional binary of the text and its address allows to fully understand the potential autosuggestive effect of the artistic image, which happens partially due to the strategic decisions of the addresser, who is a key figure in the communicative process, whose main purpose is to form a metaphorical image. Behind each poetic text we can recognize a linguistic personality. Therefore, the image of the author-addresser is present in the literary text and is much easier to reconstruct than the addressee, because the text is an objectification of the author's thought and language, and, consequently, mainly an expression of their personality. The peculiarity of the addresser of a poetic text is that they always coincide with the real author, who at the same time appears as an in-text subject of speech and an out-of-text subject as a real author. The addressee may have different ways of presentation in the text - from the explication 
of the position of the subject of speech to generalization with the recipients, but they are a holistic communicator. Each speech genre creates its own concept of the addressee. In particular, poetic discourse is characterized by expressiveness of addressee.

\section{Conclusions and prospects for further research}

Thus, in poetry the author-speaker (addresser) plays a special communicative role: he interacts with the reader-addressee through the text, influences its perception, directs the vector of development of the reader's perception. In this way, the communicative function of the author-speaker is expanded, whose role is not limited to the creation of a verbal and artistic whole, but can determine the linguistic-mental basis of the behavior of subjects of discourse and their representation. Behind each literary text, behind each metaphor, the «Ego» of the speaker is recognized, which in poetry appears mostly as a subject of evaluation, an identifying sign (linguopersonema) of the image of both the individual addresser and the linguistic and literary generation.

The prospect of the research is the description of the text category «anthropocentrism» and its components (addresser / addressee) in semantic, pragmatic, communicative aspects.

\section{References}

Dnistrovyi A. (1999) Na smert Klio: poezii, pereklady [To the death of Klio:poetry and translations]. K.: Smoloskyp.

Kosmeda T. (2012) Ego i Alter Ego Tarasa Shevchenka v komunikatyvnomu prostori shchodennykovoho dyskursu [Ego and Alter Ego of Taras Shevchenko in the communicative area of diary discourse]: monohrafiia. Drohobych: Kolo.

Kruk H (1995) Misto metelykiv [The city of butterflies]. K.: Suchasnist. no. 11, pp. 5-9.

Radziievska T. (2010) Narysy z kontseptualnoho analizu ta linhvistyky tekstu. Tekst - sotsium kultura - movna osobystist [Essays on conceptual analysis and text linguistics. Text - societyculture - linguistic personality]: monohrafiia. K.: Informormatsiino-analitychne ahenstvo.

Selivanova O. (2006) Suchasna linhvistyka: terminolohichna entsyklopediia [Modern linguistics: a terminological encyclopedia]. Poltava: Dovkillia. 